\title{
SYSTEM OF EVALUATION OF PERFORMANCE INDICATORS OF SUPPLY CHAINS
}

\author{
O. M. Zagursky
}

National University of Life and Environmental Sciences of Ukraine, Ukraine.

Corresponding authors: zagurskiy_oleg@ukr.net.

Article history: Received: March 2019. Received in the revised form: April 2019. Accepted: August 2019. Bibl. 12, fig. 3, tabl. 1.

\begin{abstract}
The article analyzes the existing systems of measuring the efficiency of supply chains and proposes a new approach based on a combination of methods for measuring the company's total cost and a balanced system of indicators. The integrated approach proposed in this paper summarizes the indicators of assessing the efficiency of supply chain operation in a complex system that meets the long-term business development strategies of the needs of customers and the needs of society. In it performance indicators first, take into account the impact of all business processes on operating costs, working capital and long-term assets of the supply chain, and secondly, the development of relations with customers, the effectiveness of personnel management and the level of information systems development.

To implement an integrated approach to developing key performance indicators, the system combines financial and non-financial, qualitative and quantitative indicators that reflect the state and prospects of the company in a comprehensive and balanced way.
\end{abstract}

Key words: cost, efficiency, supply chain, customer, system of indicators, value of the company.

\section{Introduction}

The modern type of economy has a high degree of dynamism. It is associated with diverse manifestations, and crises. In this situation, one of the tools that can achieve competitive advantages is the integration interaction of business structures connected by material, information and financial flows in a single integrated management system - supply chain (Supply Chain Management).

\section{Formulation of problem}

It requires new innovative approaches to the formation of a system for assessing the effectiveness of its functioning, which is based not on empirical data, but on quantitative calculations. This approach permits are still at the planning stage in the supply chain to evaluate B key indicators of interest to its design and identify the best ways to improve and enhance the competitive advantage of the company. According to experts a question about the formation of the analytical basis for new approaches and methods to assess the economic efficiency of supply chain.

\section{Analysis of recent research results}

Today there are many approaches to defining indicators to measure the efficiency of supply chain, so B. Bimon leads categorization of indicators for: resources, results and flexibility [8, p. 275-292] A. Gunaksaren, C. Patel, R. McGofee offer system performance, classified by types of processes in supply chains [1, p. 336-339]. J. Key Berle identifies three categories of supply chain evaluation: time, quality, costs $[1$, p. $225-$ 230]. V. Houseman offers the distribution of indicators by types of streams [12, p. 9- 10]. Chan and Qi subdivide performance indicators into groups: quantitative (costs, time of execution of orders, use of production capacities and resources) and qualitative (consumer satisfaction, degree of flexibility, integration of information and material flows, efficiency of risk management and work of suppliers) [10, p. 209-213]. N. I. Chukraj and I. B. Mlinko, structuring the most traditional factors, form a rational system for assessing the functioning of the supply chain, which covers both general and partial indicators [7, p. 29-30].

At the same time, the study of literary sources to assess the efficiency of supply chains showed that most of the proposed for measuring system of indicators is not consistent with the overall financial success of the enterprise. What induces to improvement of existing methods of estimation and construction of new innovative approaches to measuring the efficiency of the supply chain operation.

\section{Purpose of research}

The aim of the work is to is an analysis of the existing systems of measuring the efficiency of the supply chain and developing them on the basis of a new approach that generalize performance evaluation of the effectiveness of the functioning of the supply chain in the complex system that the long-term business development strategy, customer needs and demands of society. 


\section{Results of research}

Theoretical basis of the analysis of the system of performance indicators of the supply chain operation is based on the synthesis of system and functional approaches. In the process of research, general scientific methods were used, in particular: scientific abstraction, deduction, analogy, generalization and comparison.

And cutting down the measurement system to assess the efficiency of the supply chain provide for the use of many qualitative and quantitative indicators, which in turn require the use of difficult of available information, which in most cases leads to a distorted general analysis of the effectiveness and low reliability of the results. Therefore, from our point of view, the essence of assessing the effectiveness of the supply chain operation, above all, should be to compare the results of activities and spent on their achievement of resources.

In this section, in terms of scientific and methodological framework, promising direction in assessing the effectiveness of supply chain model is a measure of the total value of which allow including track the impact of transport operations on the financial performance of the company. The most popular of these are:

\section{Strategic profit model (Dupont model)}

2. Shared value (EVA cost management)

3. The monetary value of CVA (Cash Value Added)

The model Dupont rate of return on assets ROA (return on assets - a key component models) decomposed into components: Quality and Transformation assets $\mathrm{K}$. profitability of sales and $\mathrm{R}_{\mathrm{Q}}$, and they in turn spread to other financial indicators.

$$
R O E=K_{\phi 3} \times \operatorname{ROA}\left(\frac{R_{Q}\left(\frac{N O P A T(E B I T-\text { Interests }- \text { Taxes })}{V}\right)}{K_{T}\left(\frac{V}{A(N A+O A)}\right)}\right)
$$

where: NOPAT - net profit;

$E B I T$ - profit before taxes and loans;

Interests - interest on borrowing costs;

Taxes - tax liabilities;

$V$ - net revenues from sales;

$N A$ - non - negotiable assets of the enterprise;

$O A$ - current assets of the enterprise.

The ROA indicator shows how effectively an asset is used to achieve a certain level of sales. Thus, ROA relates the profitability and value of assets, thus providing the best consolidated performance of the company.

Shareholder value chain EVA, can be defined as a set of values of entities that are part of it. According to EVA [4], the value of a company is its book value, increased by the present value of future EVA. Obviously, the largest increase in the value of any company is primarily due to its investment activity, which can be realized both at its own expense and at the expense of borrowed sources. The main idea that justifies the feasibility of using economic value added is that investors (in the name of which owners can act) companies should receive a return rate for their risk. In other words, the company's capital must earn, at least, the same return rate as similar investment risks in the capital markets. There are two basic options for calculating the EVA:
1) $E V A=$ NOPAT - WACC $\times$ Capital emploed

where: WACC - weighted average cost of capital; Capital employed - investment capital.

or:

2) $E V A=($ ROI $-W A C C) \times$ Capital emploed where: $R O I$ - rate of return on invested capital

The EVA score can be increased: at the expense of increase of the income from the sale and reduction of the cost (saving and optimization of current expenses (reduction of unprofitable productions, etc. etc.)); at the expense of optimization of expenses on a capital.

Indicator cash value added ( $p V A$ ). The idea of money to this value is as follows: from the net cash flow should be deducted costs associated with the value of attracted capital. Cash Value Added VA - This is a modified EVA, in which the net operating cash flow is used instead of profit. It follows from this that the value added avoids the problem of accounting for accounting costs associated with depreciation, which rarely corresponds to the actual scheme for obtaining benefits from long-term assets.

CVA = Gross Cash Flow - Economic Depreciation Capital Charge [10]

where: Gross Cash Flow - gross cash flow;

Economic Depreciation is the economic depreciation calculated according to the formula [WACC / (1 + WACC) $\mathrm{n}-1]$;

Capital Charge - accruals for fixed assets (dividends)

The indicator of monetary value added according to its name and as a consequence of continuity of the EVA indicator is based not on accounting but on economic indicators. In particular, the CVA used economic equity, which will ignore the accounting principle of "successful efforts" and include investments in intangible assets, including "NDDKR", advertising, and more.

The analyzed models are clearly consistent with the overall financial success of the enterprise and show the effectiveness of the use of resources and financial results from activities. Their use is in line with the goal of maximizing profits in the short run, which is fully consistent with the current goals of domestic business.

However, this approach is in the long run is not effective, because the main driver of enterprise development, according to the experience of advanced foreign and companies, are clients. And in most cases, they do not get any direct benefit from reducing you spending within the supply chain, as the price of the product at the same time rarely decreases. Therefore, the evaluation of efficiency of the supply chain on the basis of the total cost is wrong. Despite of the fact that the level of direct costs affects overall profitability, this is just one of many other factors that need to be taken into account. There are indicators that characterize the development of customer relations, personnel management, product quality, the efficiency of internal business processes, the implementation and development of information systems, that is, those aspects of activity that it is not always possible to give a value assessment, however, they, like no other, meet the strategic goals of the company with business development.

The attempt to link the strategic goals of the organization with the operational level of management in 
financial and non-financial indicators was the development by R. Kaplan and D. Norton of balanced scorecard (balanced scorecard) [2], which is by far the most popular and recognized worldwide management concept economic efficiency. Balanced Scorecard (SSM) is a system of strategic management of a company based on measurement and evaluation of its effectiveness by recruiting optimally (or rationally) selected indicators that reflect these aspects of the organization's activities (financial and non-financial).

What exactly "balances" in the SSM? First, targeting short-term goals and indicators that reflect them are balanced with the long-term goals of the company. Secondly, external evaluations of the company (in the financial and client constituents) are balanced with internal (in the components of internal business processes and innovations and training). Third, the leading indicators that reflect the desired results and the factors affecting their achievement eye $\mathrm{u} \mathrm{t} \mathrm{b}$ be delayed along with indicators that already occurred. Finally, there are both objective (eg financial) and subjective (eg, image) assessments in the system.

The SSM provides interaction between the employees of the company at all levels of enterprise management and gives an idea of how the decisionmaking process can be improved and come closer to the goals set. By participating in identifying key indicators and implementing a strategy, employees have the opportunity to increase their own qualifications and improve the efficiency of the enterprise as a whole. Due to the involvement of staff in the process of implementing strategic decisions, the company becomes a flexible structure, where each employee equally understands the goals set. Such an enterprise is able to quickly respond to dangerous trends and make appropriate management decisions. H. Boulinger and $M$. Kuhner were using models SSM, to assess the effectiveness of the supply chain, offer to group indicators by four projections: 1) The financial aspect (the level of costs and stocks, return on investment, the financial cycle), 2) aspect of the client (the level of customer satisfaction, timely supply, time of execution of the order, level of service), 3) the internal economic aspect (accuracy of the execution of the order), 4) aspect of innovation (the proportion of sales of a new product) [9, p. 3535-3540]. The biggest development of the concept of applying MSP received in the D. Part of the era [5], in which the key indicators of activity (Key Performance Indicators - KPI).

KPI - quantitative or qualitative indicators, that allow to measure the degree of goal achievement that company is facing, a structural unit, a group of positions or post. With the introduction of KPI it is possible to create an individual benchmark for employees. KPI include - key performance indicators (KPI), production figures (PF) and key performance indicators (KPIs). Number of KPI and their ratio in the total structure of SSM determined directly by management companies. However, good recommendation is a rule of "10/80/10", which means that SSM with her assessment of the organization should be included around $10 \mathrm{key}$ performance indicators to 80 production indicators and $10 \mathrm{key}$ performance indicators. In very rarely cases, more than the estimated parameters are required - usually they are even less.

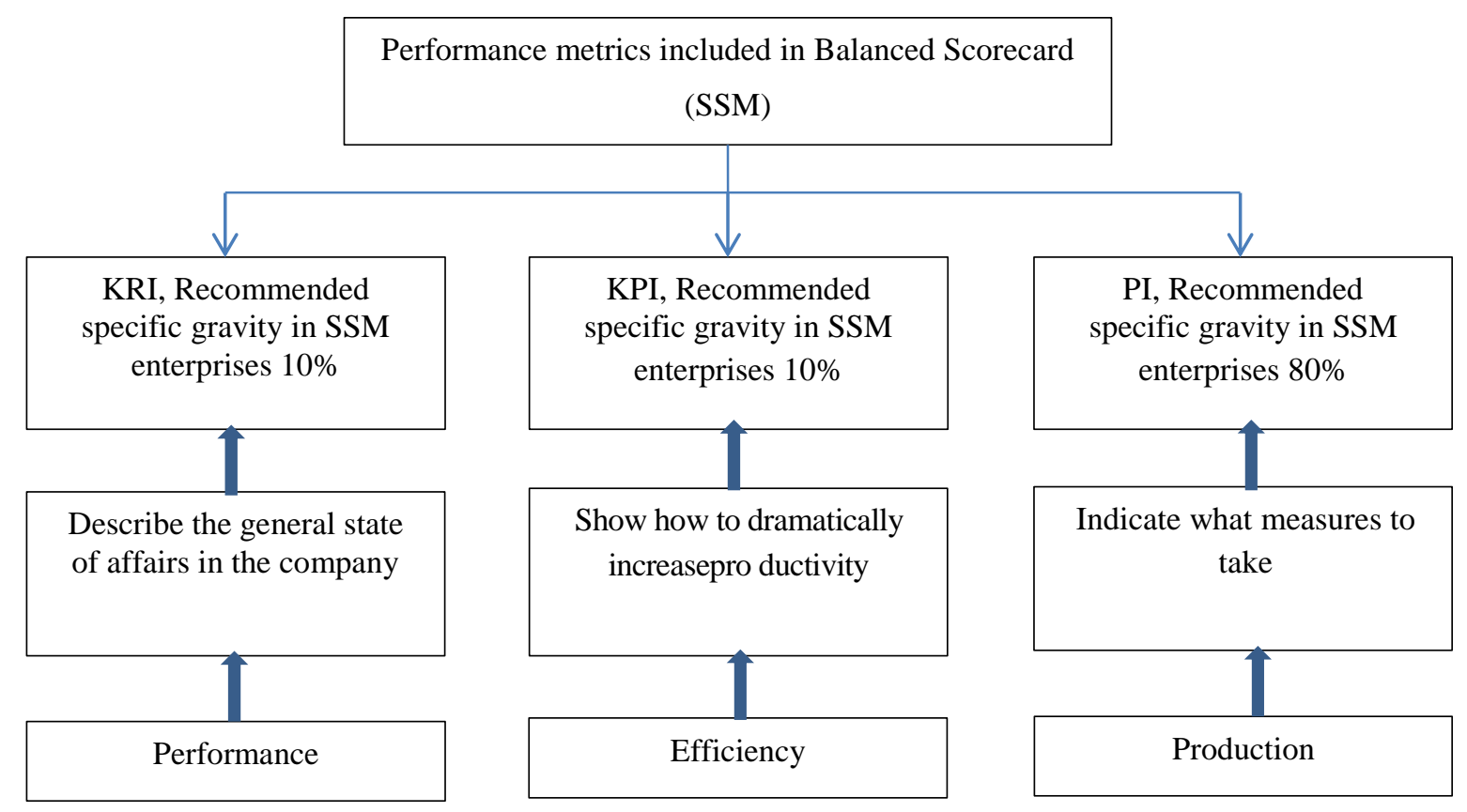

Fig. 1. Indexes efficiency Lanka hectare supply.

Source: Parmenter D. Key Performance Indicators. Development, implementation and application of decisive indicators: monograph [Per. from english A. Platonov]. Moscow. ZAO "Olympus - Business", 2008. 288.

A similar approach to measuring the performance of supply chains is presented in the Gower publication [6] (with the exception of performance indicators), where performance and productivity indicators are entered into quadrants in the context of existing and future key indicators. The general characteristic of these parameters is that they reflect the results of many activities and give a clear view of the correctness of the direction of movement 
of companies supply chain participants. However, they do not say anything about how to improve these results. So, this kind of indicators is very convenient for board members (i.e. etc. For people who are not involved in the daily management of the companies that make up the supply chain).

Logical continuation of the widespread use of the concept of key performance indicators (KPIs) are outside the SSM. They allow you to link the implementation of the plan with the main results of the management of the chains and post the result and determine the necessary corrective action. KPIs should be measured once a week, every day, and in some cases, every hour. In this way, they are current indicators either indicators of future periods, which show that it is necessary to do this directly today to increase the efficiency of the supply chain.

Within the KPI administration, it is proposed to refuse to use only financial indicators to assess the company's performance and focus on non-financial indicators that assess the level of customer satisfaction, the efficiency of internal administrative and technological processes, and the potential of service personnel - these indicators, in turn, provide financial success of the company. It takes into account those indicators, the connection between which is difficult to describe by formalized methods. Non-financial indicators are by and large outperforming, since they allow timely decisions to be taken to prevent certain situations and adequately assess the processes taking place in the company, as well as provide long-term managerial impacts. At the same time, financial indicators are recognized as effective criteria for success. Financial efficiency is measured by short-term indicators, which, as a rule, leads to short-term managerial influences.

One of the options of the system of indicators, which allows in general to assess the efficiency and effectiveness of the supply chain operation are: general logistics costs (KPE-1); quality of logistic service (KPE2); duration of logistic cycles (KPE-3); performance (KPE-4); Return on Investment in Logistics Infrastructure (KPE-5) [3]. These indicators are key and complex. In addition to the key, additional indicators are allocated: performance (effectiveness) and efficiency, PIi and Pie, respectively. The general classification of indicators can be presented in the form of a scheme (Figure 2).

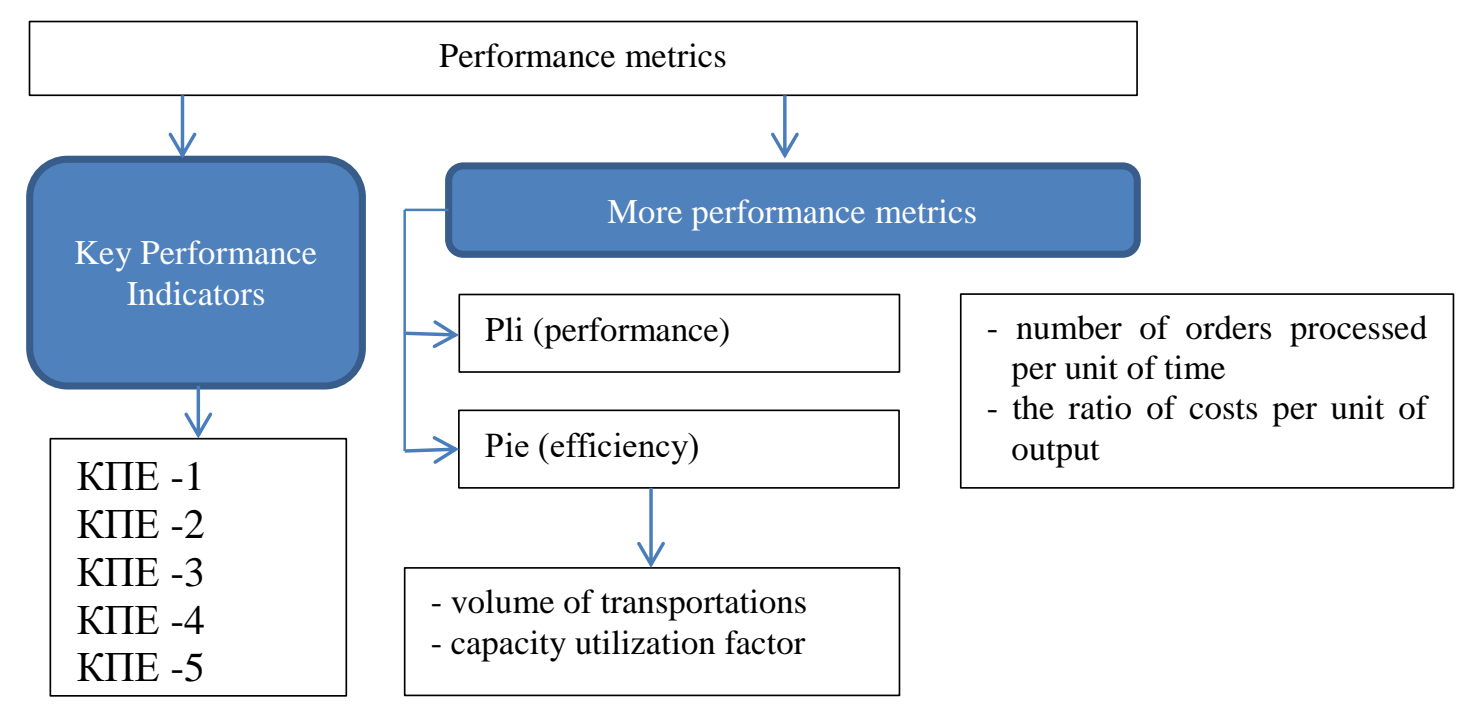

Fig. 2. Performance indicators in the supply chain. Source: prepared by the author

In world practice, key performance indicators of the KPI are an integral part of not only assessing certain technological and business processes, but also management systems.

However, due to the current development of global economic processes, special attention should be paid to the introduction of new indicators, involving experts in the process of analysis. They can be executives, as well as the most trained specialists of financial and commercial structures of enterprises, analysts of specialized consulting companies, etc.

Taking into account the experience in the field of forward studies, we consider the methods of assessing the efficiency of supply chains based on the use of RPM most rational and reflecting all aspects of the organization's activities. However, new approaches to building a system of performance indicators for supply chains should be designed in such a way that they firstly take into account the impact of all business processes on operating costs, working capital and long-term assets of the supply chain, and secondly, the development of relations with customers, the effectiveness of personnel management, the quality of internal business processes and the level of implementation and development of information systems of the organization. Under this logic, we propose the use of five key areas (finance, customer relations, internal business processes, relationships with the environment, training and development).

The first direction (Finance) provides an understanding of the financial position and financial stability of the Company and shareholders and investors (both actual and potential); the second (customer relationship) - reflects the point of view of customers, that is, gives an idea of the ratio of consumers to the company's products; third (internal business processes) displays information about the quality of internal business 
processes and the level of implementation and development of information systems in the company; fourth (relations with the external environment) characterizes the level of external socially responsible relations of the company, within which the process of creating values for the enterprise itself and consumers, the state, business partners; fifth (training and development) helps to disassemble be the work of staff in the middle of and understand what opportunities exist for growth and development.

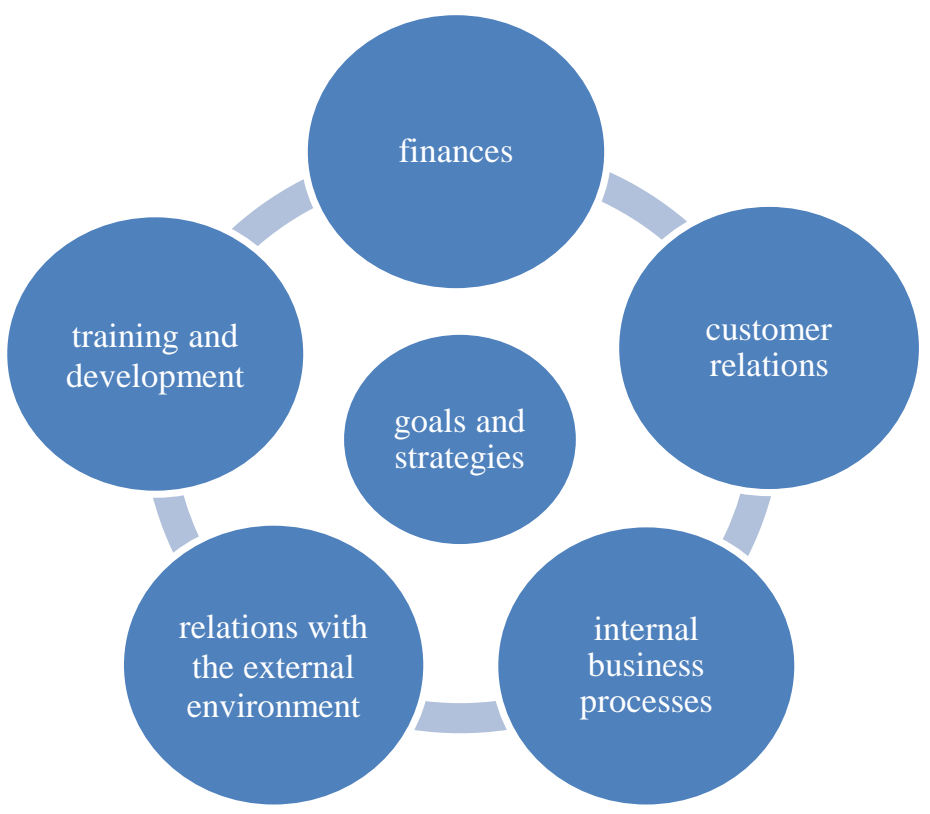

Fig. 3. Directions with Balanced Scorecard.

Source: prepared by the author

The identified directions are linked by a strategic cause-and- effect chain. Causal links that bind all of these blocks, show the logic inherent in the company's business, which should lead to success.

The set of key indicators of efficiency within defined directions depends on the level of development of management of a particular company. To implement a systemic approach to developing key performance indicators, it is proposed to combine both financial and non-financial, qualitative and quantitative indicators (Table 1).

Table 1. Indicators for assessing the efficiency of the supply chain.

\begin{tabular}{|c|c|}
\hline Direction & Indicator \\
\hline Finances & $\begin{array}{l}\text { - } \text { return on assets (ROA) } \\
\text { - } \text { return on equity (RO E) } \\
\text { - } \text { monetary value added (VA) } \\
\text { - } \text { asset turnover } \\
\text { - } \text { marginal income from the use of assets }\end{array}$ \\
\hline relations with clients & $\begin{array}{l}\text { - } \text { share of lost customers } \\
\text { - customer satisfaction level } \\
\text { - the level of product value for the customer } \\
\text { - availability of company product information for the customer }\end{array}$ \\
\hline internal business processes & $\begin{array}{l}\text { - time of order execution } \\
\text { - flexibility of product configuration change } \\
\text { - delivery flexibility } \\
\text { - flexibility in providing the required volumes of the order } \\
\text { - the processing speed of receipt of the order }\end{array}$ \\
\hline social responsibility & $\begin{array}{l}\text { - the effectiveness of environmental protection } \\
\text { - rational consumption and use of natural resources in } \\
\text { - level of energy consumption of products } \\
\text { - level of safety of production and production } \\
\text { - level socio th investment }\end{array}$ \\
\hline training and development & $\begin{array}{l}\text { - } \text { staff costs } \\
\text { - level of staff turnover } \\
\text { - the cost of information } \\
\text { - } \text { the level of ineffective use of information }\end{array}$ \\
\hline
\end{tabular}

Source: prepared by the author 
Such a system of key indicators of the efficiency of the supply chain will provide support for decision-making by specialists at the stage of their design and operation. What will allow managers to create a coherent picture of how their company should develop, help them prioritize and anticipate the consequences of their decisions in terms of achieving strategic goals. Thus, the company's management becomes strategically and socially oriented, which is extremely relevant and popular today.

It should be noted that a certain number of indicators is quite sufficient for a comprehensive assessment of the efficiency of the supply chain operation, but if necessary, the clarification of certain criteria may be extended.

\section{Conclusions}

1. Developed through a combination of methods the total value of the company and the system of balanced indicators approach generalizes system of indicators to measure the efficiency of the supply chain and serves as a tool to determine its level. Proposed system is developed as a way to show nicks efficiency of the supply chain firstly take into account the impact of all executables it business processes operating expenses, working capital and the asset supply chain and secondly, the development of relations with customers, the effectiveness of personnel management, the quality of internal business processes and the implementation and development of information systems. To implement a systematic approach to the development of key performance indicators in the system combined financial and non-financial, qualitative and quantitative indicators.

2. Further researches in the context of this problem should be aimed at data accumulation and analysis of the efficiency of the functioning of supply chains of Ukrainian enterprises.

\section{References}

1.Gunasekaran A., Patel' S., MakGofi R. E. (2004). Supply Chain Performance Scope. Mezhdunarodnyj zhurnal jekonomiki proizvodstva. Vol. 3, 333-347. [in Russian].

2.Kaplan R., Norton D. (2003). Balanced scorecard. From strategy to action. ZAO «Olimp-Biznes», Moskva [in Russian].

3.Kouplend T., Koller T. (2005). Value of companies - evaluation and management. ZAO «Olimp-Biznes», Moskva [in Russian].

4.Parmenter D. (2015). Key performance indicators. Development, implementation and application of decisive indicators. ZAO «Olimp-Biznes», Moskva [in Russian]

5.Gatorny Dzh. (2008). Supply Chain Management: A Directory of Publishers Gower; 5rd ed. INFRA-M, Moskva [in Russian].

6. Chukhraj N. I., Mlynko I. B. (2013). Evaluating the effectiveness and efficiency of marketing an industrial enterprise in the supply chain. Marketynh i menedzhment innovatsij. Vol. 3, 24-34. [in Ukrainian].
7.Beamon B. M. (1999). Measuring supply chain performance. International Journal of Production Management. 275-292.

8.Bullinger, H. J., Kuhner M. (2002). Analysing supply chain performance using a balanced measurement method. International Journal of Production Research. Vol. 40. 3533-3543.

9.Chan, F. T. S., Qi, H. J. (2003). An innovative performance measurement method for supply chain management. Supply Chain Management: An International Journal. Vol. 3. 209-223.

10. Fernandez P. (2002). Three Residual Income Valuation Methods And Discounted Cash Flow Valuation. Madrid IESE Business School, [Online], available at: http://pruss.narod.ru/ThreeIncome_ OneDCF.pdf

11. Hausman W. (2019). Financial Flows \& Supply Chain Efficiency/Visa Commercial Solutions [Online], available at: http://www.visa-asia.com/ap/sea/ commercial/corporates/includes/uploads/Supply_Chain_ Management_Visa.pdf.

12. Keebler, J. S., Manrodt K. B., Durtsche D. A., Ledyard D. M. (1999). Keeping Score: Measuring the Business Value of Logistics in the Supply Chain. Oak Brook, IL: Council of Logistics Management.

\section{Список літератури}

1.Gunasekaran A., Patel' S., MakGofi R. E. Supply Chain Performance Scope. Mezhdunarodnyj zhurnal jekonomiki proizvodstva. 2004. Vol. 3. P. 333-347. [in Russian].

2.Kaplan R., Norton D. Balanced scorecard. From strategy to action. ZAO «Olimp-Biznes», Moskva. 2003. [in Russian].

3. Kouplend T., Koller T. Value of companies evaluation and management. 2005. ZAO «Olimp-Biznes», Moskva [in Russian].

4.Parmenter D. Key performance indicators. Development, implementation and application of decisive indicators. 2015. ZAO «Olimp-Biznes», Moskva [in Russian]

5.Gatorny Dzh. Supply Chain Management: A Directory of Publishers Gower; 2008. 5rd ed. INFRAM, Moskva [in Russian].

6. Chukhraj N. I., Mlynko I. B. Evaluating the effectiveness and efficiency of marketing an industrial enterprise in the supply chain. Marketynh i menedzhment innovatsij. 2013. Vol. 3, P. 24-34. [in Ukrainian].

7.Beamon B. M. Measuring supply chain performance. International Journal of Production Management. 1999. P. 275-292.

8.Bullinger, H. J., Kuhner M. Analysing supply chain performance using a balanced measurement method. International Journal of Production Research. 2002. Vol. 40. P. 3533-3543.

9.Chan, F. T. S., Qi, H. J. An innovative performance measurement method for supply chain management. Supply Chain Management: An International Journal. 2003. Vol. 3. P. 209-223.

10. Fernandez $P$. Three Residual Income Valuation Methods And Discounted Cash Flow Valuation. 2002. 
Madrid IESE Business School, [Online], available at: http://pruss.narod.ru/ThreeIncome_OneDCF.pdf

11. Hausman W. Financial Flows \& Supply Chain Efficiency/Visa Commercial Solutions [Online], available at: http://www.visa-asia.com/ap/sea/ commercial/ corporates/includes/uploads/Supply_Chain_Management_ Visa.pdf. 2019.

12. Keebler, J. S., Manrodt K. B., Durtsche D. A., Ledyard D. M. Keeping Score: Measuring the Business Value of Logistics in the Supply Chain. 1999. Oak Brook, IL: Council of Logistics Management.

\section{СИСТЕМА ОЦІНКИ ПОКАЗНИКІВ ЕФЕКТИВНОСТІ ЛАНЦЮГІВ ПОСТАЧАННЯ О. М. Загурський}

Анотація. Транспортні організації виступають на товарних В статті проведено аналіз існуючих систем вимірювання ефективності ланцюгів постачання та запропоновано новий підхід, що оснований на поєднанні методів вимірювання загальної вартості компанії та збалансованої системи показників.

Запропонований інтегрований підхід узагальнює показники оцінки ефективності функціонування ланцюгів постачання у комплексну систему, яка відповідає довгостроковим стратегіям розвитку бізнесу, потребам клієнтів і запитам суспільства. В ньому показники ефективності по-перше, враховують вплив усіх бізнес-процесів на операційні витрати, оборотний капітал і довгострокові активи ланцюга постачання i по-друге характеризують розвиток відносин 3 клієнтами, ефективність управління персоналом та рівень розвитку інформаційних систем.

Для реалізації інтегрованого підходу до розробки ключових показників ефективності в системі скомбіновано фінансові та нефінансові, якісні та кількісні показники, які комплексно і збалансовано відображають стан та перспективи розвитку компанії.

Ключові слова: вартість, ефективність, ланцюг постачання, клієнт, система показників, цінність компанії.

\section{СИСТЕМА ОЦЕНКИ ПОКАЗАТЕЛЕЙ ЭФФЕКТИВНОСТИ ЦЕПЕЙ ПОСТАВОК О. Н. Загурский}

Аннотация. В статье проведен анализ существующих систем измерения эффективности цепей поставок и предложен новый подход, основанный на сочетании методов измерения общей стоимости компании и сбалансированной системы показателей.

Предложенный интегрированный подход обобщает показатели оценки эффективности функционирования цепей поставок в комплексную систему, которая отвечает долгосрочным стратегиям развития бизнеса, потребностям клиентов и запросам общества. В нем показатели эффективности, вопервых, учитывают влияние всех бизнес-процессов на операционные расходы, оборотный капитал и долгосрочные активы цепи поставок и во-вторых характеризуют развитие отношений с клиентами, эффективность управления персоналом и уровень развития информационных систем.

Для реализации интегрированного подхода к разработке ключевых показателей эффективности в системе скомбинированы финансовые и нефинансовые, качественные и количественные показатели, которые комплексно и сбалансировано отражающих состояние и перспективы развития компании.

Ключевые слова: стоимость, эффективность, цепь поставок, клиент, система показателей, ценность компании.

O. M. Zagursky ORCID 0000-0002-5407-8466. 
